\title{
Intellectual and thematic structure of Communication research in Scopus (1980-2020). A comparative perspective among Spain, Europe, and Latin America
}

\author{
Francisco Segado-Boj; Salvador Gómez-García; Jesús Díaz-Campo
}

Nota: Este artículo se puede leer en español en:

https://revista.profesionaldelainformacion.com/index.php/EPI/article/view/86577

How to cite this article:

Segado-Boj, Francisco; Gómez-García, Salvador; Díaz-Campo, Jesús (2022). "Intellectual and thematic structure of Communication research in Scopus (1980-2020). A comparative perspective among Spain, Europe, and Latin America". Profesional de la información, v. 31, n. 1, e310110.

https://doi.org/10.3145/epi.2022.ene.10

Article received on July $7^{\text {th }} 2021$

Approved on December $14^{\text {rd }} 2021$

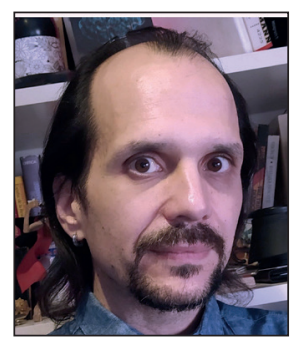

Francisco Segado-Boj $\triangle$ https://orcid.org/0000-0001-7750-3755

Universidad Complutense de Madrid Facultad de Ciencias de la Información

Av. Complutense, 3

28040 Madrid, Spain

fsegado@ucm.es

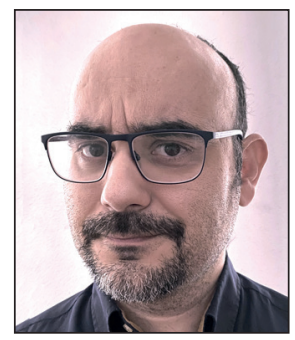

Salvador Gómez-García

https://orcid.org/0000-0001-5126-6464

Universidad de Valladolid

Facultad de Filosofía y Letras

PI. Campus Universitario, $\mathrm{s} / \mathrm{n}$.

47011 Valladolid, Spain

salvadorgomez@hmca.uva.es

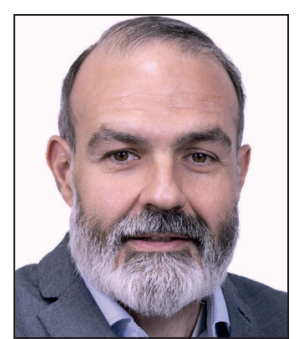

Jesús Díaz-Campo

https://orcid.org/0000-0001-5014-8749

Universidad Internacional de la Rioja

Facultad de Empresa y Comunicación

Avenida de la Paz, 137

26006 Logroño, Spain

jesus.diaz@unir.net

\begin{abstract}
The late incorporation of Spain into the international circuit for the publication of results of scientific research in Communication has not proved to be an obstacle to reaching a level similar to international research in this discipline recently. However, this development is still subject to some obstacles. In this study, we carried out co-word and cocitation analyses of the intellectual and thematic structure of articles published by researchers affiliated with Spanish centers in journals indexed in the Communication category in Scopus and published between 1980 and $2020(n=7,422)$. This enables an analysis of the intellectual and thematic structure of Communication studies between 1980 and 2020 and its evolution. The aim is to contextualize this process, in a broad sense, thus establishing the similarities to and differences from European $(n=33,615)$ and Latin American $(n=5,160)$ Communication research during the same period. The results reveal a homogenization of the research interests between Spanish academics and their European counterparts during the last decade, with an emphasis on digital technologies and social networks. The first prominent studies in Spanish research have also appeared, albeit not yet becoming established as such on the international stage during the last decade. It is concluded that Spanish Communication research has developed around Journalism while the other classic disciplines (Audiovisual Communication, and Advertising and Public Relations) have not managed to consolidate a coherent and cohesive thematic and intellectual community to date, mainly due to their greater heterogeneity.
\end{abstract}




\section{Keywords}

Network analysis; Cocitation; Communication; Scholarly communication; Audiovisual communication; Co-words; InteIlectual structure; Thematic structure; Spain; Europe; Latin America; Metaresearch; Journalism; Advertising; Public Relations; Scopus.

\section{Funding}

This article has been funded by 1 ) the project Communication and health in social networks (Comsadi) developed by the Communication and Digital Society research group (Coysodi) within the framework of the call for R\&D Projects challenges 2020-2021 of the International University of La Rioja (UNIR); 2) the project "Politainment ante la fragmentación mediática: desintermediación, engagement y polarización" (PID2020-114193RB-I00) financed by the Ministry of Science and Innovation (2021-2024); and 3) the project "Cartografia de los discursos del odio en España desde la comunicacion: ámbito deportivo, taurino y político" (PID2019-105613GB) of the Ministry of Economy and Competitiveness (Spain).

\section{Introduction}

Scientific Communication research started in Spain later than in the rest of Europe, the USA, or some Latin American countries. This discipline did not begin to develop as an area of knowledge in Spain until the creation and consolidation of the first Faculties of Information (or Communication) Sciences (Jones, 1998), which celebrated their $50^{\text {th }}$ anniversary in 2021.

Alongside the emergence of Spanish Communication research (Saperas-Lapiedra, 2016), a stream of studies on the field itself proliferated (Martínez-Nicolás; Saperas-Lapiedra; Carrasco-Campos, 2019), analyzing its characteristics as a scientific discipline based on metaresearch (Giménez-Toledo; Jiménez-Contreras, 2013). In this regard, various studies have analyzed the centers and authors who publish most (Baladrón-Pazos; Manchado-Pérez; Correyero-Ruiz, 2017), their social structure (Repiso-Caballero; Torres-Salinas; Delgado-López-Cózar, 2011), their objects of study (Caffarel-Serra; Ortega-Mohedano; Gaitán-Moya, 2017), or the most widely applied methodologies (Martínez-Nicolás; Saperas-Lapiedra, 2011).

These studies illustrate various features of the evolution in this field. Thus, at the end of the 1990s, Spanish Communication research focused on mass communication, especially via traditional media, to the detriment of other facets such as personal or intergroup communication (Jones, 1998). From that time to the present, the focus of this discipline in Spain has remained on the content of mass communication, to the detriment of institutional or social aspects (audiences) (Martínez-Nicolás; Saperas-Lapiedra; Carrasco-Campos, 2019).

On the other hand, Spanish Communication research has developed beyond its initial phase marked by articles with an essayistic or theoretical nature or weak methodology toward the current generalization and consolidation of empirical research (Martínez-Nicolás, 2020), especially regarding content analysis (Castillo-Esparcia; Carretón-Ballester, 2010; Gómez-Escalonilla, 2020). This evolution has placed Spain at levels close or comparable to international Communication research (Goyanes; Rodríguez-Gómez; Rosique-Cedillo, 2018; Vizoso; Pérez-Seijo; López-García, 2019).

This intellectual evolution has been accompanied by publication with more collaborative dynamics (Fernández-Quijada; Masip; Bergillos, 2013; Martínez-Nicolás, 2020), a stronger orientation toward not only Spanish but also international journals (Fernández-Quijada; Masip, 2013; Martínez-Nicolás, 2020), and greater intensity (Rodríguez-Gómez; Goyanes; Rosique-Cedillo, 2018; De-Filippo, 2013). In fact, the Scopus database rates Spain as one of the most productive countries in the Communication field, only surpassed by the USA and UK (Trabadela-Robles et al., 2020).

However, this panorama has been described by studies that have only occasionally considered all publications in journals in the area indexed in Scopus or WoS. Different lines of research have focused on articles published in journals published in Spain (Castillo-Esparcia; Carretón-Ballester, 2010; De-Filippo, 2013; Míguez-González; Baamonde-Silva; Corbacho-Valencia, 2014; Martínez-Nicolás, 2020), doctoral theses (Repiso-Caballero; Torres-Salinas; Delgado-López-Cózar, 2011; Marcos-Recio; Martínez-Pestaña; Blasco-López, 2012; Díaz-Campo, 2016; Lozano-Ascencio et al., 2020), or in certain subdisciplines (Díaz-Campo; Segado-Boj, 2017) or under the auspices of the conferences of national associations (Castillo-Esparcia; Carretón-Ballester; Pineda-Martínez, 2020).

Studies sampling all journals in the area that are indexed in databases such as Scopus or Web of Science have been restricted to specific fields of the discipline such as Organizational Communication (Míguez-González; Costa-Sánchez, 2019) or television (Moreno-Delgado; Repiso; Montero-Díaz, 2020), or have ignored the thematic and intellectual dimension to focus on other dimensions such as social structure (Escribà-Sales; Cortiñas, 2013; Segado-Boj; Prieto-Gutiérrez; Díaz-Campo, 2021) or the productivity and impact of authors (Túñez-López, 2013; Spanish research in Scopus has evolved from technical and linguistic aspects to issues related to new technologies and, especially, social networks 
The aim of the current work is to complement this perspective by considering all articles published by researchers affiliated to Spanish centers in journals indexed in the Scopus Communication category, regardless of the nationality of those journals. It has been pointed out that the evolution of the internationalization of this area (Fernández-Quijada; Masip, 2013) is one of the characteristics illustrating its maturity, especially as an effect of the introduction of the Agencia Nacional de Evaluación de la Calidad y Acreditación (Aneca), the National Agency for Quality Assessment and Accreditation of Spain) (Masip, 2011). Not considering scientific publications by Spanish researchers in international journals will thus ignore a growing proportion of Spanish Communication results.

On the other hand, this work also aims to compare Spanish Communication research with that carried out in the European and Latin American scenarios. Segado-Boj, Prieto-Gutiérrez, and Díaz-Campo (2021) point out that international collaboration by Spanish researchers is oriented more toward Europe and the English-speaking world, while there is no consolidated Latin American research community in Communication. This disconnection between Latin America and Spain does not only occur in relations between researchers. Piñeiro-Naval and Morais (2019) also highlight a thematic and intellectual disconnection: while in Spain positivist works (surveys) are published on the audience and their interaction with ICT and social networks, in Latin America there are more qualitative analyses on cinematographic messages, although other authors (González-Samé; Romero-Rodríguez; Aguaded, 2017) have also indicated that Latin American research is fundamentally dedicated to the analysis of messages and their impact on the audience.

Finally, this study also presents for the first time a structural analysis of the intellectual and thematic networks of Spanish Communication research.

\subsection{Aims}

This study aims to analyze the intellectual and thematic structural evolution of Spanish Communication research between 1980 and 2020 in articles published in journals indexed in the Communication category of Scopus. The intellectual structure is comprehended as how the study topics are connected to each other, while their thematic structure is considered to describe the connection between the most cited works, which can reveal theoretical schools or traditions (Segado-Boj; Martin-Quevedo; Fernández-Gómez, 2022).

We also compare the extent to which these structures coincide with research published by European and Latin American academics, and its longitudinal evolution over the years.

The following research questions are thus proposed:

$\mathrm{RQ}_{1}$ : How was the intellectual structure of Spanish Communication research organized between 1980 and 2020 ?

$\mathrm{RQ}_{2}$ : How was the thematic structure of Spanish Communication research structured between 1980 and 2020 ?

$\mathrm{RQ}_{3}$ : How did these structures evolve in each decade? What changes occurred in their composition and configuration?

$\mathrm{RQ}_{4}$ : What are the similarities and differences of the intellectual and conceptual structure of this research when compared with European and Latin American Communication research?

\section{Methodology}

The intellectual and conceptual structure of this research field is studied by carrying out a sociometric analysis of the coword and cocitation networks (García-Lillo et al., 2017; Aparicio; Iturralde; Maseda, 2019). Co-word analysis considers keyword co-occurrences, that is, the number of times that two or more keywords are used together in a single article.

The second element of the sociometric analysis, based on cocitation networks, captures the frequency with which two documents are cited by the same subsequent work (Small, 1973). Cocitation analysis can thus identify the theories and ideas that constitute the intellectual foundations of a discipline (Cheng et al., 2018).

Each network is made up of vertices or nodes (keywords or cited references), linked by a network or relationships that represent how many times each term or reference appears together in a document. The indices calculated to identify the structure of the networks are detailed below.

\subsection{Number of nodes}

This index indicates the total number of elements (either keywords or references) composing each network.

\subsection{Components}

Within a network, different components can be configured, that is, combinations of elements or nodes connected to each other within the universe of the network (Sosa; Eppinger; Rowles, 2007). A high number of components may indicate a fragmented community or the existence of specialized communities (Fatt; Ujum; Ratnavelu, 2010).

The size of the main component measures the percentage of vertices included in the largest set in the network. A large main component may indicate the extent to which the discipline is structured around a fundamental or transversal theme (Segado-Boj; Prieto-Gutiérrez; Díaz-Campo, 2021). 


\subsection{Clustering and transitivity coefficient}

Networks may include different communities or clusters whose nodes interact more frequently and intensely with each other than with the rest of the network. The clustering coefficient computes the proportion of vertices connected to a node that in turn are also connected to each other (Zhu; Guan, 2013). That is, it calculates the probability that a node will appear linked to other neighboring nodes within its community. The higher the clustering index, the more closely these communities will be connected (Yan; Ding; Zhu, 2010).

The transitivity also indicates the clustering of the network, but unlike the clustering coefficient, it is calculated on the basis of the vertices with the greatest centrality. Thus, a low transitivity index indicates that the network comprises communities divided among themselves and that barely connect with each other, only weakly or infrequently. In contrast, a high transitivity index indicates that the network cannot be differentiated into distinguishable communities (Hicks et al., 2019).

\subsection{Centrality}

The centrality of a network indicates the degree to which only one or a few vertices tend to show a large number of connections (Schoen et al., 2014). An index equal to 1 would imply that a node would be linked to all the nodes of the network while the rest of the vertices would be connected only to that initial node, giving rise to a star-shaped graph. On the contrary, an index equal to 0 would indicate that all the nodes are equally connected to each other, which can be represented by a circular graph (Olmeda-Gómez et al., 2008).

A high number of nodes in certain networks may require the application of a network reduction strategy (Tang; Teng; Lin, 2019) to enable a structural analysis. The increase in nodes during the period 2010-2020 made it necessary to divide this decade into two five-year periods (2011-2015 and 2016-2020) for the purposes of the structural analysis of the network. In addition, the cocitation networks for all the periods were generated only from references cited at least twice.

\subsection{Material}

The bibliographic material used to construct the networks was downloaded from Scopus in March 2021. All journals indexed at that time in the Communication category of the latest edition of SCImago Journal Rank (2019) were searched using ISSN. This initial search was refined into three subsets comprising articles with at least one author affiliated to a Spanish, European, or Latin American institution, respectively. The Communication area shows a relatively low degree of internationalization, which will reduce the overlap between these three subsets (Trabadela-Robles et al., 2020). A database of 45,556 articles published by authors affiliated to Spanish, Latin American, or European institutions was thereby constructed (Table 1).

Table 1. Sample composition by decade

\begin{tabular}{|l|c|c|c|}
\cline { 2 - 4 } \multicolumn{1}{c|}{} & $\mathbf{1 9 8 1 - 1 9 9 0}$ & $\mathbf{1 9 9 1 - 2 0 0 0}$ & $\mathbf{2 0 0 1 - 2 0 1 0}$ \\
\hline Spain & 15 & 130 & 922 \\
\hline Europe & 1,172 & 2,508 & 7,221 \\
\hline Latin America & 19 & 33 & 580 \\
\hline Individual articles & 1,206 & 2,671 & 8,216 \\
\hline
\end{tabular}

The bibliographic information from these databases was transformed into sociometric information using VOSviewer (Van-Eck; Waltman, 2010). Subsequently, one of the authors manually processed and homogenized the keywords and references. The generated networks were analyzed and represented graphically using Pajek (Batagelj; Mrvar, 1998). The visual representation was achieved by using a twofold simplification strategy. In all cases (Figs. 1-12), only the 50 keywords and the 25 most used references in each decade and geographical setting considered were taken into account. Information available at:

https://doi.org10.6084/m9.figshare.17194946

Additionally, in each particular case, only relationships between vertices that reached a given minimum frequency (indicated below each figure) are presented.

The visual representations also include the identification of communities as detected using the Leuven algorithm (multilevel thickening, single refinement, resolution parameter $=1$, number of random restarts $=1$, maximum number of levels in each iteration $=20$, maximum number of repetitions at each level $=50$ ). The color of the nodes in each figure corresponds to the different communities identified by the algorithm in each network. The number inside each node corresponds to the frequency of appearance of each keyword and the number of citations of each reference, as appropriate.

The "Results" section also presents the information for each decade. Firstly, the thematic structure of the community is described on the basis of the keywords, then the intellectual structure according to the most frequent citations.

The small number of references found for the years 1981-1990 and 1991-2000 prevented the generation of networks. For the decades 2001-2010 and 2011-2020, the co-word and cocitation networks are presented first for Spain and then for Europe and Latin America. 


\section{Results}

First, an epigraph is presented to illustrate the structural evolution of the keyword and cocitation networks during the period analyzed. The data are presented in a disaggregated manner for Spain, Europe, and Latin America during each period considered.

After this information, a visual representation of the networks is provided. First, information on the co-word and cocitation networks of the Spanish sample is presented, followed by a comparison with the situation in Europe and Latin America.

\subsection{Structural evolution of networks}

\subsubsection{Co-word network}

Alongside the increase in Spanish scientific production in the Communication field (Table 1), the numbers of nodes and components also increased (Table 2); That is, the variety of keywords used increased greatly, and in turn the disconnected word groups. However, the size of the main component in Spanish production grew steadily during the decades considered: the proportion of connected increased throughout, since the 1980s. A similar trend is observed for the European and Latin American production, with Spain lying closer in size to the main European component and slightly exceeding that from Latin America.

The centrality indices of the Spanish network evolve with variations that are more marked during 1981-2000 but become more moderate from 2001 onward. In any case, these values are at relatively low levels, indicating the absence of terms or concepts with excessively high prominence and, on the contrary, pointing to a certain dispersion in the thematic focus.

Meanwhile, the European production exhibits an upward trend, more uniformly in the case of centrality, albeit remaining at moderate values. The Latin American network again shows an uneven evolution in its centrality, remaining lower than that for the Spanish network. The Spanish co-word network is more structured around certain concepts than the Latin American one, which shows a more dispersed character in this sense.

Regarding the grouping of the communities, the three analyzed scenarios share a similar evolution. Both the clustering coefficient and the transitivity decrease progressively and stably. Connections within and between co-word communities become increasingly weak and infrequent. However, the clustering coefficient remains at values much higher than the transitivity, which falls at rates that barely reach one tenth (in the European case) or slightly exceed it (in Spain and Latin America).

Table 2. Structural characteristics of co-word networks

\begin{tabular}{|c|c|c|c|c|c|c|}
\hline & & 1981-1990 & 1991-2000 & 2001-2010 & 2011-2015 & 2016-2020 \\
\hline \multirow{7}{*}{ Spain } & Number of nodes & 16 & 92 & 2,794 & 6,868 & 10,087 \\
\hline & Number of components & 3 & 10 & 98 & 151 & 149 \\
\hline & Main component & 9 & 36 & 2,275 & 6,191 & 9,387 \\
\hline & Main component percentage & 56.25 & 39.13 & 81.42 & 90.14 & 93.06 \\
\hline & Clustering & 0.946 & 0.971 & 0.904 & 0.875 & 0.868 \\
\hline & Transitivity & 0.875 & 0.605 & 0.250 & 0.124 & 0.103 \\
\hline & Centrality & 0.238 & 0.336 & 0.095 & 0.097 & 0.131 \\
\hline \multirow{7}{*}{ Europe } & Number of nodes & 487 & 1,822 & 11,892 & 18,739 & 32,187 \\
\hline & Number of components & 43 & 104 & 313 & 348 & 441 \\
\hline & Main component & 252 & 1,303 & 10,580 & 17,153 & 30,057 \\
\hline & Main component percentage & 51.75 & 71.52 & 88.97 & 91.54 & 93.38 \\
\hline & Clustering & 0.933 & 0.911 & 0.878 & 0.871 & 0.864 \\
\hline & Transitivity & 0.700 & 0.456 & 0.152 & 0.112 & 0.076 \\
\hline & Centrality & 0.053 & 0.045 & 0.049 & 0.068 & 0.083 \\
\hline \multirow{7}{*}{ Latin America } & Number of nodes & & 48 & 1,493 & 3,770 & 6,282 \\
\hline & Number of components & & 7 & 76 & 169 & 195 \\
\hline & Main component & & 13 & 1,170 & 3,060 & 5,412 \\
\hline & Main component percentage & & 27.08 & 78.37 & 81.17 & 86.15 \\
\hline & Clustering & & 0.989 & 0.885 & 0.881 & 0.876 \\
\hline & Transitivity & & 0.955 & 0.355 & 0.208 & 0.161 \\
\hline & Centrality & & 0.139 & 0.044 & 0.039 & 0.048 \\
\hline
\end{tabular}

Note: no results are presented for Latin America for the period 1981-1990 because of the small numbers of documents and occurrences 


\subsubsection{Cocitation network}

Broadly speaking, the structural characteristics of the Spanish cocitation network and its evolution are similar to those of the co-word network. Its number of vertices increases throughout the period, and the number of components during the last years, while the size of its main component grows; That is, an increasing number of references are cited, there are fewer and fewer groups of references that are disconnected from others, and there is increasingly a nucleus of references linked more to each other. Furthermore, the clustering coefficient and transitivity are decreasing, while the centrality remains at low levels (Table 3 ). The intellectual connection between references is decreasing, while the "center of gravity" of the network shifts towards a greater diversity of nodes.

\section{Spanish research on Communication is organized in a more cohesive way around certain common themes but it is not yet organized around common inte- llectual references}

One can highlight certain differences regarding the moments at which changes in the trends or the magnitude of certain indicators occur. Indeed, the growth of the main component in Spain starts later than in the case of the co-word network. In the same way, the cocitation network does not exhibit an increase in its main component until 2011-2015.

The clustering coefficient shows lower levels, especially from 2016 onward. In contrast, the transitivity of the cocitation network is significantly higher during all the periods considered.

The centrality is limited to low values, albeit closer to zero than in the case of the co-word network. These values suggest that one can speak of a widely decentralized cocitation network as well.

The comparison with Europe and Latin America indicates that this reduction in the number of components is a phenomenon that is particular to the Spanish network. The European and Latin American networks are regularly and continuously divided into an ever-growing set of separate components.

The main component is smaller than that of the European production, but larger than that for Latin America. Specifically, although the size of the main component of the Spanish network is closer to that of the European network, it is almost 15 percentage points above that of the Latin American network during the last five years.

The Spanish grouping coefficient shows values similar to those for Latin America, but slightly higher than those for Europe. The main difference is found in the transitivity, which is significantly higher in the Latin American case but lower in the European context.

The centrality of the Spanish network is close to that of Latin America but shows only a marginal difference from the European one.

Table 3. Structural characteristics of cocitation networks

\begin{tabular}{|c|c|c|c|c|c|c|}
\hline & & 1981-1990 & 1991-2000 & 2001-2010 & 2011-2015 & 2016-2020 \\
\hline \multirow{7}{*}{ Spain } & Number of nodes & 4 & 20 & 368 & 2,007 & 3,773 \\
\hline & Number of components & 2 & 9 & 66 & 173 & 155 \\
\hline & Main component & 3 & 5 & 92 & 1,450 & 3,397 \\
\hline & Main component percentage & 75 & 25 & 25 & 72.247 & 90.034 \\
\hline & Clustering & 1 & 1 & 0.84 & 0.831 & 0.681 \\
\hline & Transitivity & 1 & 1 & 0.796 & 0.770 & 0.491 \\
\hline & Centrality & 0.333 & 0.111 & 0.079 & 0.053 & 0.069 \\
\hline \multirow{7}{*}{ Europe } & Number of nodes & 16 & 1,597 & 7,719 & 14,397 & 30,106 \\
\hline & Number of components & 3 & 115 & 209 & 237 & 280 \\
\hline & Main component & 9 & 1,245 & 7,283 & 13,747 & 29,479 \\
\hline & Main component percentage & 56.25 & 77.96 & 94.35 & 95.49 & 97.92 \\
\hline & Clustering & 0.946 & 0.725 & 0.624 & 0.608 & 0.561 \\
\hline & Transitivity & 0.875 & 0.594 & 0.356 & 0.265 & 0.193 \\
\hline & Centrality & 0.238 & 0.048 & 0.052 & 0.092 & 0.106 \\
\hline \multirow{7}{*}{ Latin America } & Number of nodes & & & 246 & 813 & 1,373 \\
\hline & Number of components & & & 39 & 97 & 174 \\
\hline & Main component & & & 153 & 534 & 1,046 \\
\hline & Main component percentage & & & 62.20 & 65.68 & 76.18 \\
\hline & Clustering & & & 0.702 & 0.745 & 0.682 \\
\hline & Transitivity & & & 0.686 & 0.766 & 0.644 \\
\hline & Centrality & & & 0.108 & 0.052 & 0.071 \\
\hline
\end{tabular}

Note: no results are presented for Latin America for the period 1981-2000 because of the small number of documents and occurrences 


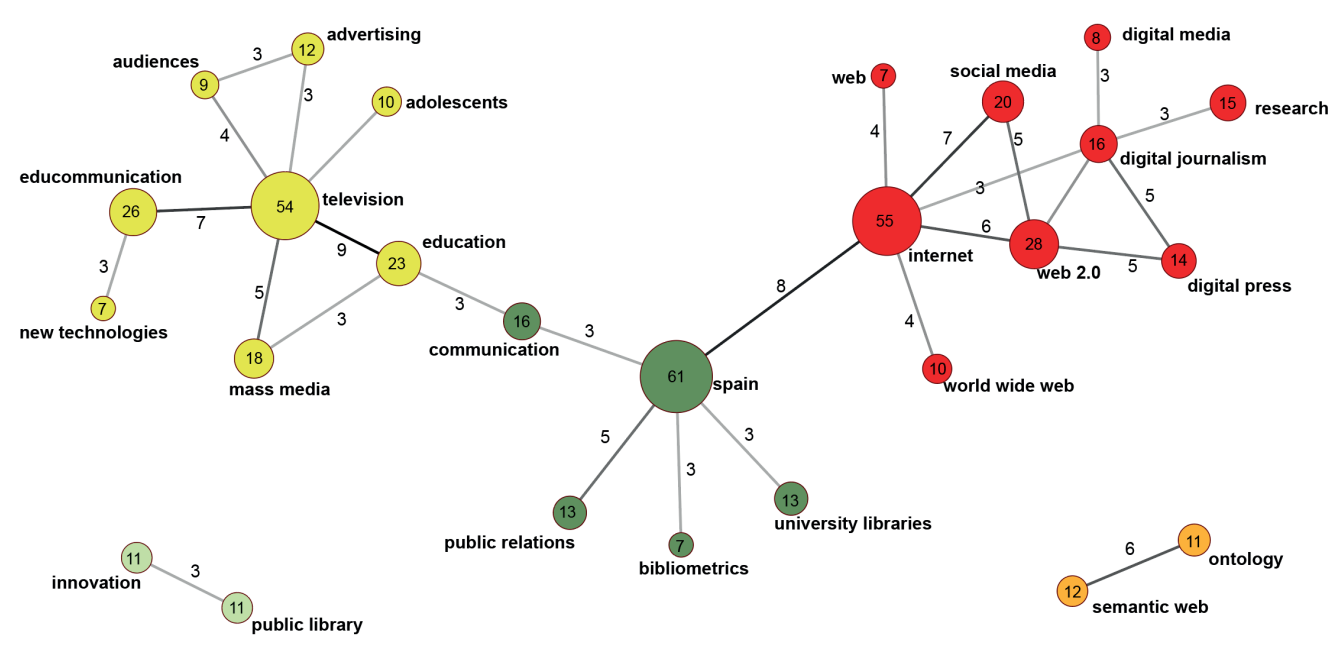

Figure 1. Network of the most frequent co-words of the Spanish Communication literature in Scopus (2001-2010). Note: Only relationships with three or more occurrences are included.

\subsection{Concept and intellectual map}

The 1980s and 1990s do not allow the generation of networks, as pointed out in the "Methodology" section. For this reason, the construction of the conceptual and intellectual maps for Spain, Europe, and Latin America begins in the decade 2001-2010.

\subsubsection{Local studies and interest in} the media (2001-2010)

The Spanish co-word network is structured around a main component that can be divided into two clusters united by a central community around the term "Spain"

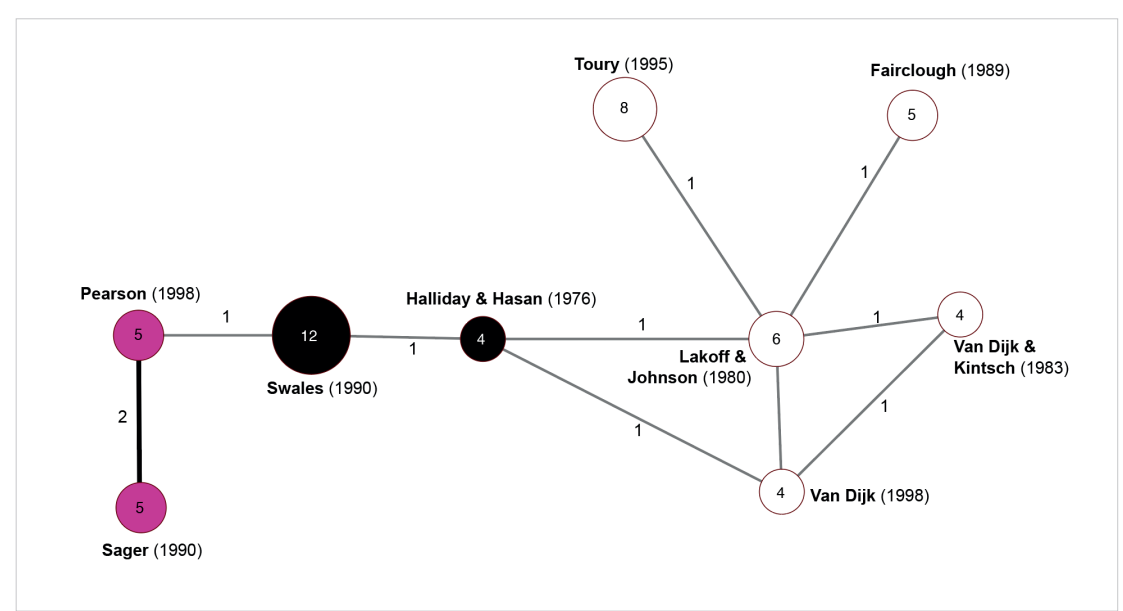

Figure 2. Cocitation network of the most cited references in Spanish Communication literature in Scopus (2001-2010).

(Fig. 1). This central community (in green) includes some elements linked to Library \& Information Sciences (university libraires, bibliometrics) and to Communication issues that fail to constitute their own community (public relations). The other two communities are structured around the concepts of television (in yellow) and the internet (in red). Television is more frequently linked to adolescence and education and educommunication, in contrast to its potential for entertainment, which is barely represented. At the other extreme is a community structured around the internet and other terms related to digital technologies such as the web, World Wide Web, or Web 2.0. The appearance of attention to communication and digital journalism is thus highlighted. Finally, beyond the main component, there are two dyads with terms typical of Library \& Information Sciences (the light green and orange communities).

Regarding the intellectual structure, a group of central references in the discipline focused on discourse analysis is identified (Fig. 2). One article (Toury, 1995) that is closer to translation is also included in this group. At the periphery of the network appear articles oriented towards language processing or the analysis of terms. In this decade, Spanish Communication scientific production continues to rely on references from other disciplines.

The comparison with the European network reveals several interesting differences. While in Spain journalism is mainly related to aspects of new technologies, in Europe this term is also linked to the social and political sphere (democracy, political communication) with other platforms or dimensions of mass communication such as public relations or television (Fig. 3). In this sense, journalism is a more central, less peripheral concept than in Spain.

Among the similarities, the European literature also reveals links between work on television and its orientation towards a younger audience, in this case children. Likewise, there is a community (represented in red) focused on aspects of new technologies.

On the other hand, several clusters with themes that are not present in Spain are also identified, in particular the representation of identities, especially gender (dark
The Latin American scientific production on Communication shows a particular attention towards Health 


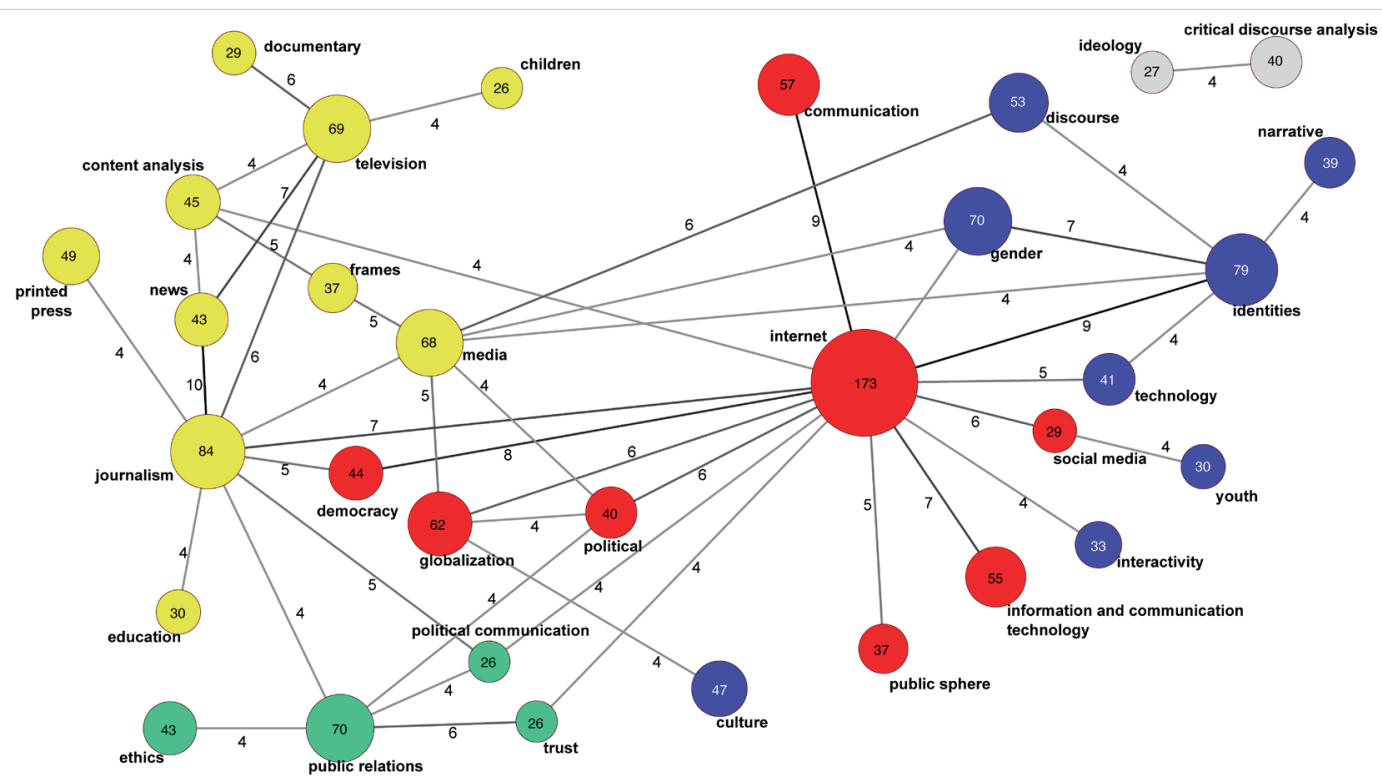

Figure 3. Network of the most frequent co-words of the Spanish Communication literature in Scopus (2001-2010). Note: Only relationships with four or more occurrences are included.

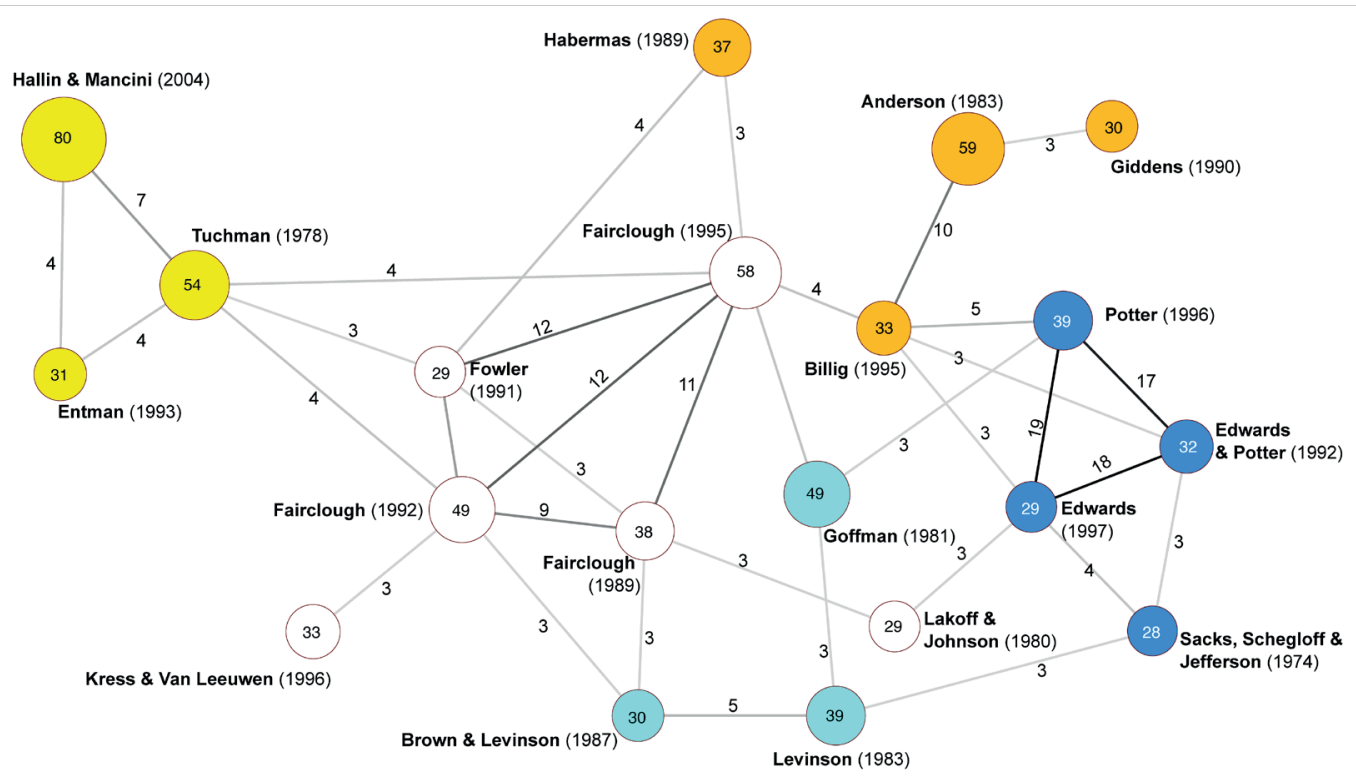

Figure 4. Cocitation network of the most cited references in European Communication literature in Scopus (2001-2010). Note: Only relationships with three or more occurrences are included.

blue), another focused on public relations, trust, and the ethical dimension (light blue), and another minor one (gray) on ideology and critical discourse analysis

The cocitation analysis suggests a different panorama from that of Spain, with a greater number of communities with different intellectual orientations that range from Sociology (Habermas, 1989; Giddens, 1990) to Political Science (Anderson, 1983; Billig, 1995), Psycholinguistics or classics from journalism studies (Hallin; Mancini, 2004) (Fig. 4). However, a distant parallel can be drawn between the Spanish network and the European community represented in white when focusing on media content (e.g., Fairclough, 1995). 


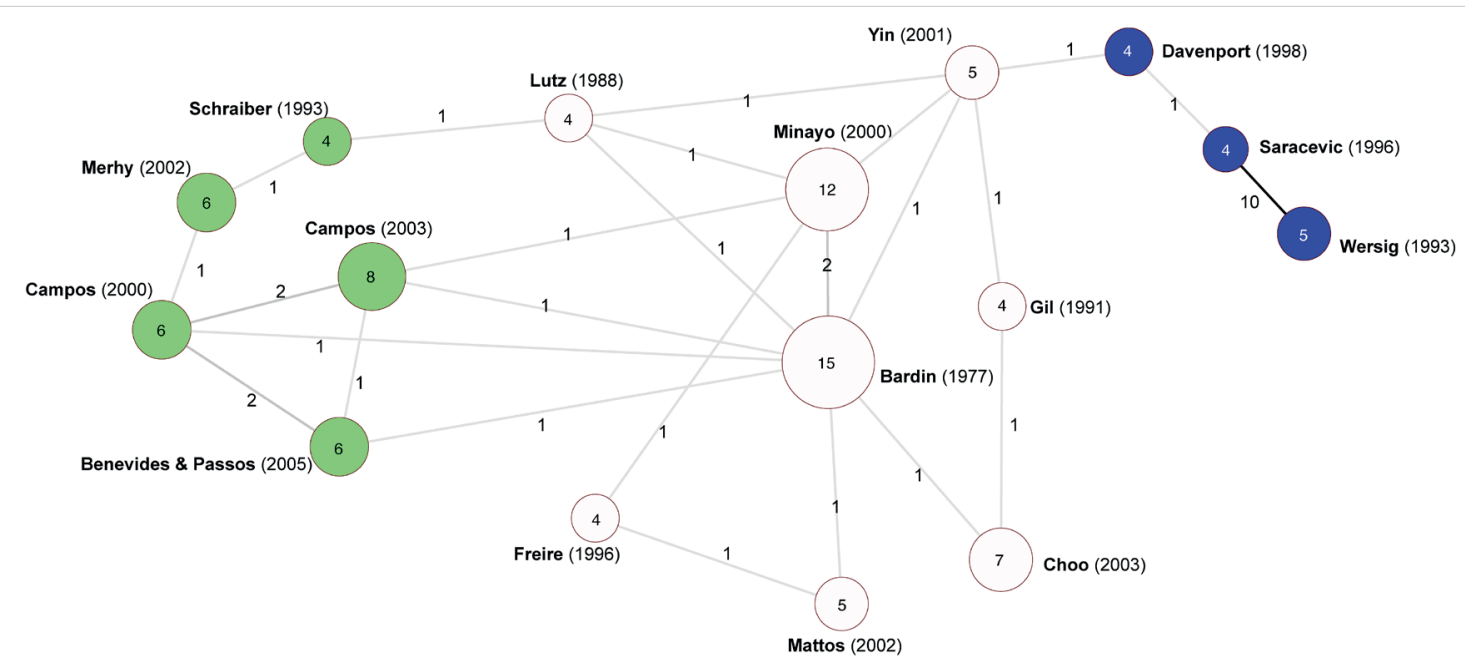

Figure 6. Cocitation network of the most cited references in Latin American Communication literature in Scopus (2001-2010).

Thus, in comparison with the European case, the Spanish cocitation network for 2001-2010 is less diverse and they do not share the same number and frequency of references in the Communication field, unlike the fields of critical philosophy, linguistics, or sociology.

The Latin American co-word network can be divided into two components of dual relationships in which health-related terms abound while the concept of Communication is peripheral (Fig. 5).

The importance of health also appears in the cocitation network (Fig. 6). In addition to works on public health, there are works on methodology that occupy a central place in the network as well as other disciplines such as Library \& Information Sciences (blue) or Education. The works on methodology (in white) are not only the most cited but also the most central in this network.

\subsubsection{The (academic) coming of age of Journalism and the hegemony of social networks (2011-2020)}

The arrangement of keywords in the Spanish network reveals a central community (red) around the concept of social networks, around which one finds terms associated with specific platforms (Twitter, Facebook), dimensions related to the active role of the audience (interactivity, participation, Web 2.0), and concepts referring to different facets of mass communication, such as public relations or, more frequently, political communication (Fig. 7).

Another cluster (blue) focuses on journalism, which acquires sufficient coherence to become an independent thematic community. This community is especially dedicated to the relationship with new technologies (digital journalism) and on

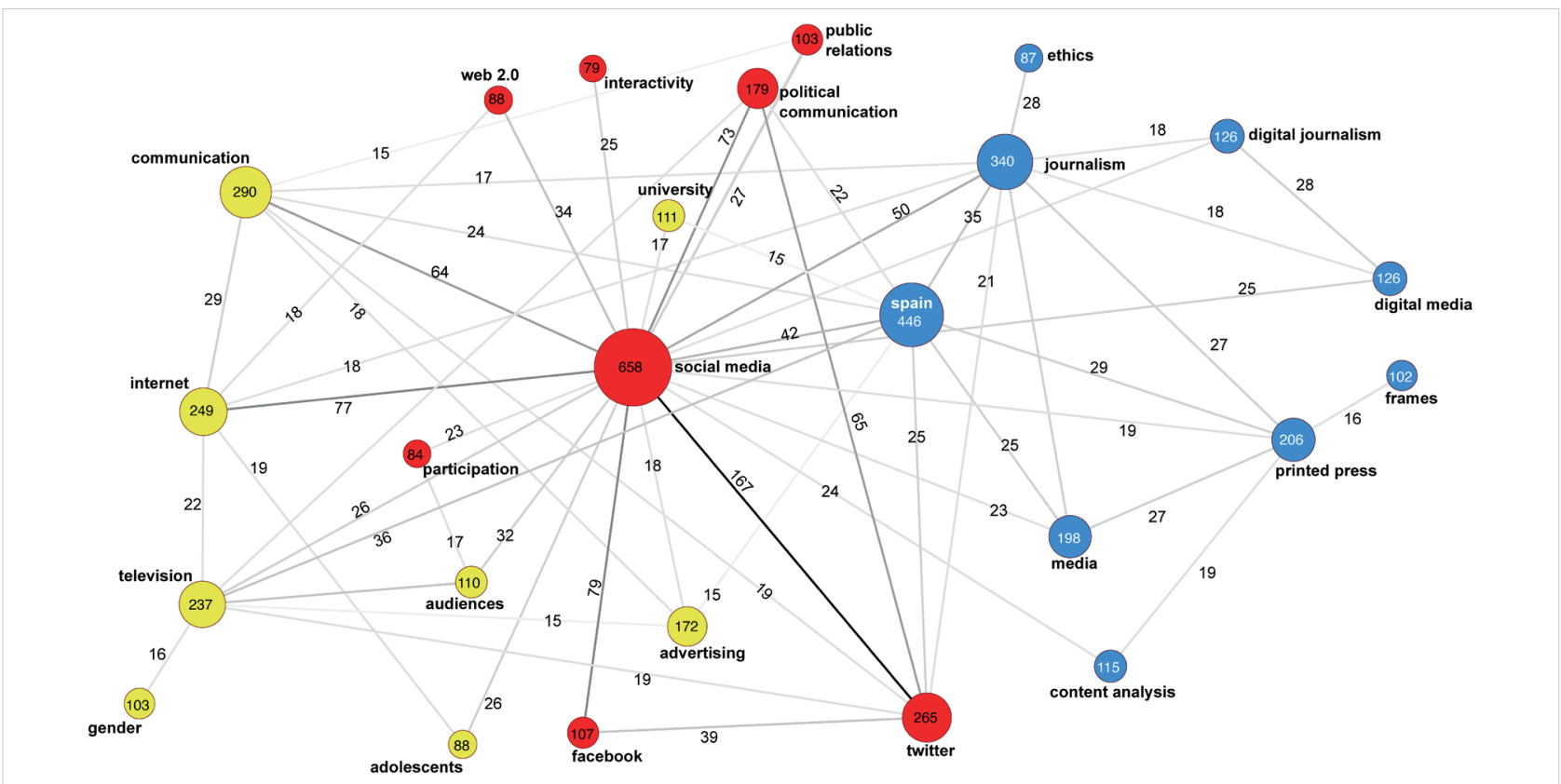

Figure 7. Network of the most frequent co-words of the Spanish Communication literature in Scopus (2011-2020). Note: Only relationships with 15 or more occurrences are included. 


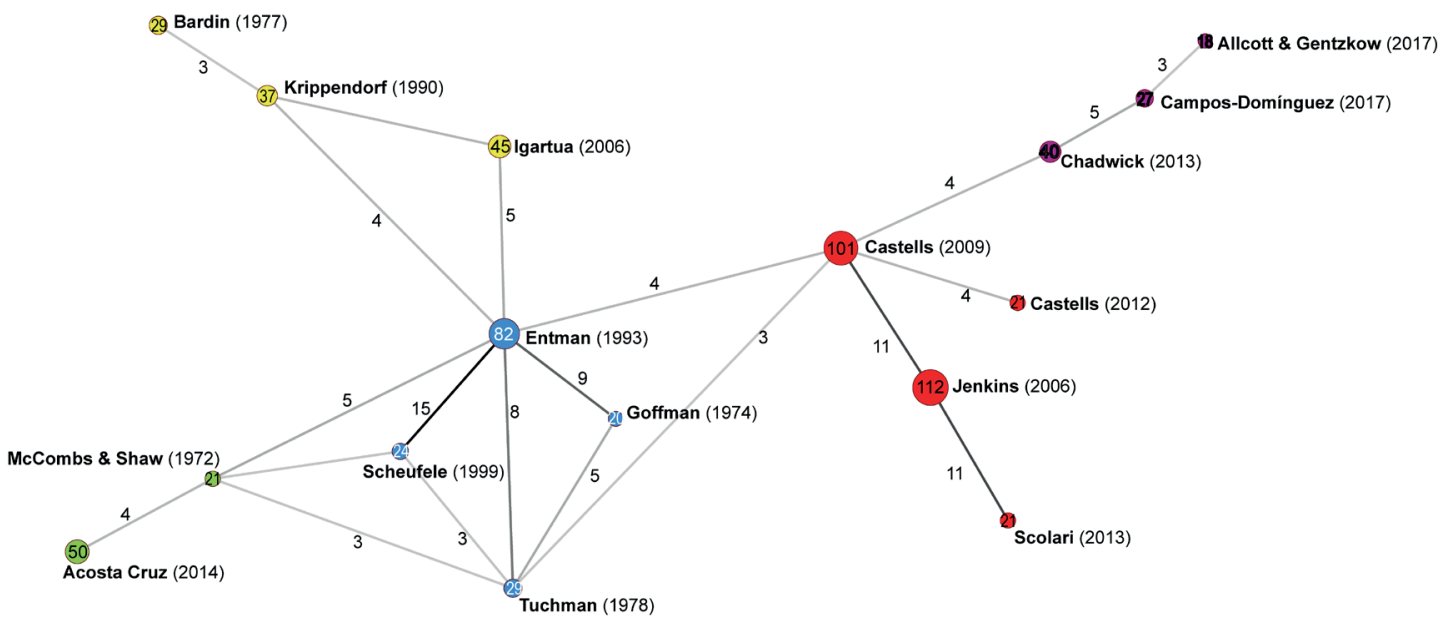

Figure 8. Cocitation network of the most cited references in Spanish Communication literature in Scopus (2011-2020). Note: Only relationships with three or more occurrences are included.

the other hand to content (content analysis, frames) and the ethical dimension of the information profession. Journalism continues to show special interest in digital media, although framing analysis is also incorporated into its conceptual repertoire.

The community represented in yellow addresses new technologies, although now labeled as the internet. It continues to be linked to television, audiences, adolescents, and advertising. The main difference from the previous period is that Education is no longer linked to this community. On the contrary, research on the internet during this period is close to political communication, in contrast to the disconnection observed between these two nodes in the previous period. This evolution partly imitates what is observed in the European co-word network for 2001-2010 (Fig. 3).

The cocitation network reveals two central communities (Fig. 8). That represented in red includes works on the effects of new media, either social (Castells, 2009; 2012) or cultural (Jenkins, 2006; Scolari, 2013). The community in blue deals with the social construction of media reality (Tuchman, 1978) with a special presence of framing (e.g., Entman, 1993). The green cluster can be understood as an extension of this community insofar as it also includes works focused on media production as part of the construction of social reality, especially in news selection (McCombs; Shaw, 1972) and cultural studies (Acosta-Cruz, 2014).

On the periphery there are two communities, one with methodological studies (yellow) and the other (purple) focused on the changes produced by new technologies (e.g., Campos-Domínguez, 2017).

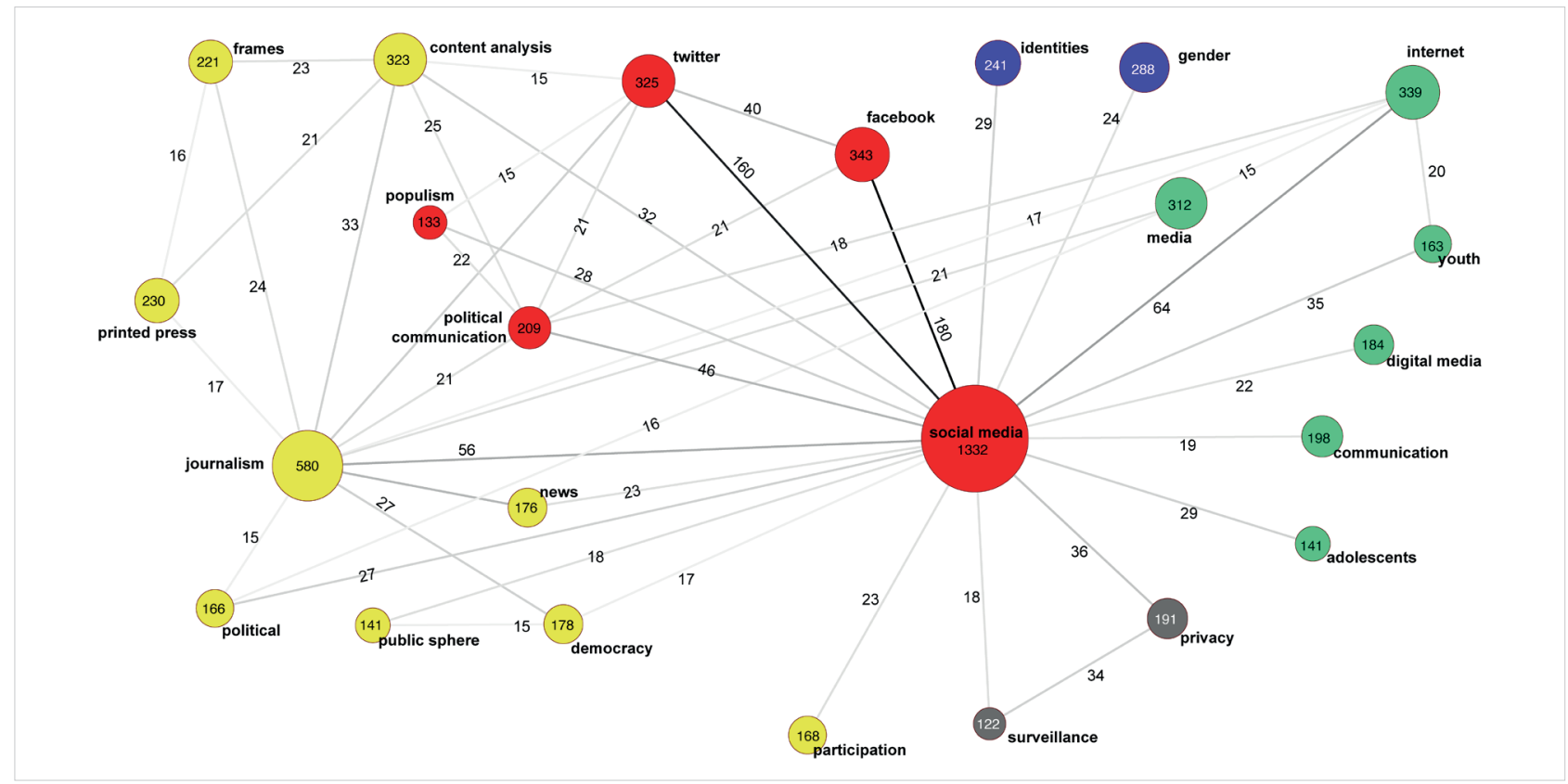

Figure 9. Network of the most frequent co-words of European Communication literature in Scopus (2011-2020). Note: Only relationships with 15 or more occurrences are included. 


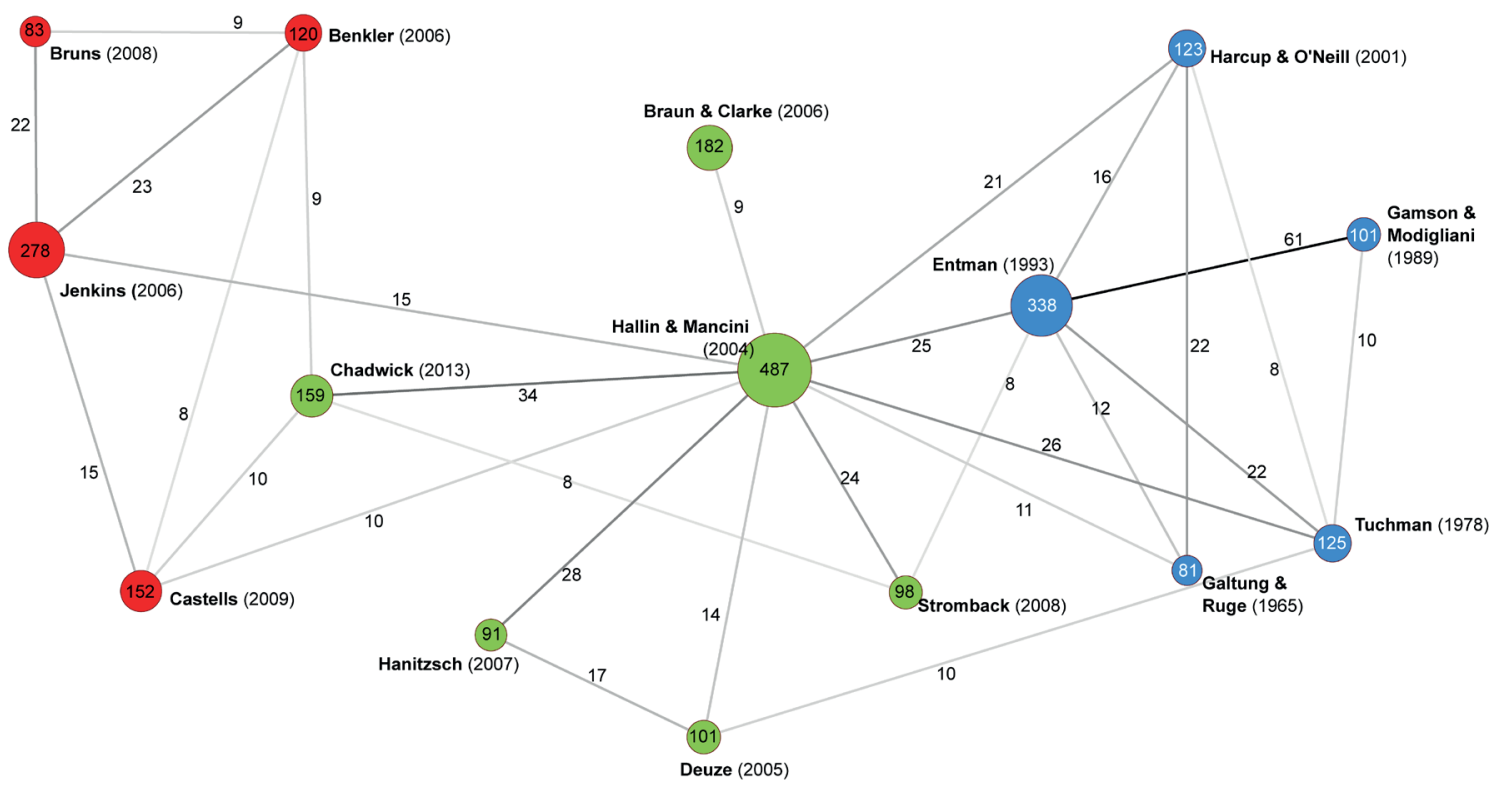

Figure 10. Cocitation network of the most cited references in European Communication literature in Scopus (2011-2020). Note: Only relationships with eight or more occurrences are included.

The European co-word network is structured around social networks, corresponding to a community (shown in red) that occupies the center of the network (Fig. 9). As in Spain, particular attention is paid to political communication, with the particularity of populism, a concept not included in the Spanish network.

Another cluster (shown in yellow) also appears around journalism, being related to the political and democratic sphere. Meanwhile, the community shown in green revolves around new technologies and their relationship with youth and adolescents. On the periphery there are two specialized communities: one (dark blue) focused on gender identity, and another (gray) focused on privacy issues.

Inspection of the European cocitation network reveals that its main similarity with the Spanish one in this period is the community about new media (red cluster), although it occupies a more secondary place than in the Spanish network (Fig. 10). The central place is occupied by a set of references linked to journalism (in green) structured around Hallin and Mancini (2004).

The blue cluster can be (distantly) assimilated with that of the same color in the Spanish network, in the sense that it deals with the analysis of media messages. In the European cocitation network, this community presents the nuance of transcending studies on framing to include theories such as that of news values (Galtung; Ruge, 1965; Harcup; O'Neill, 2001).

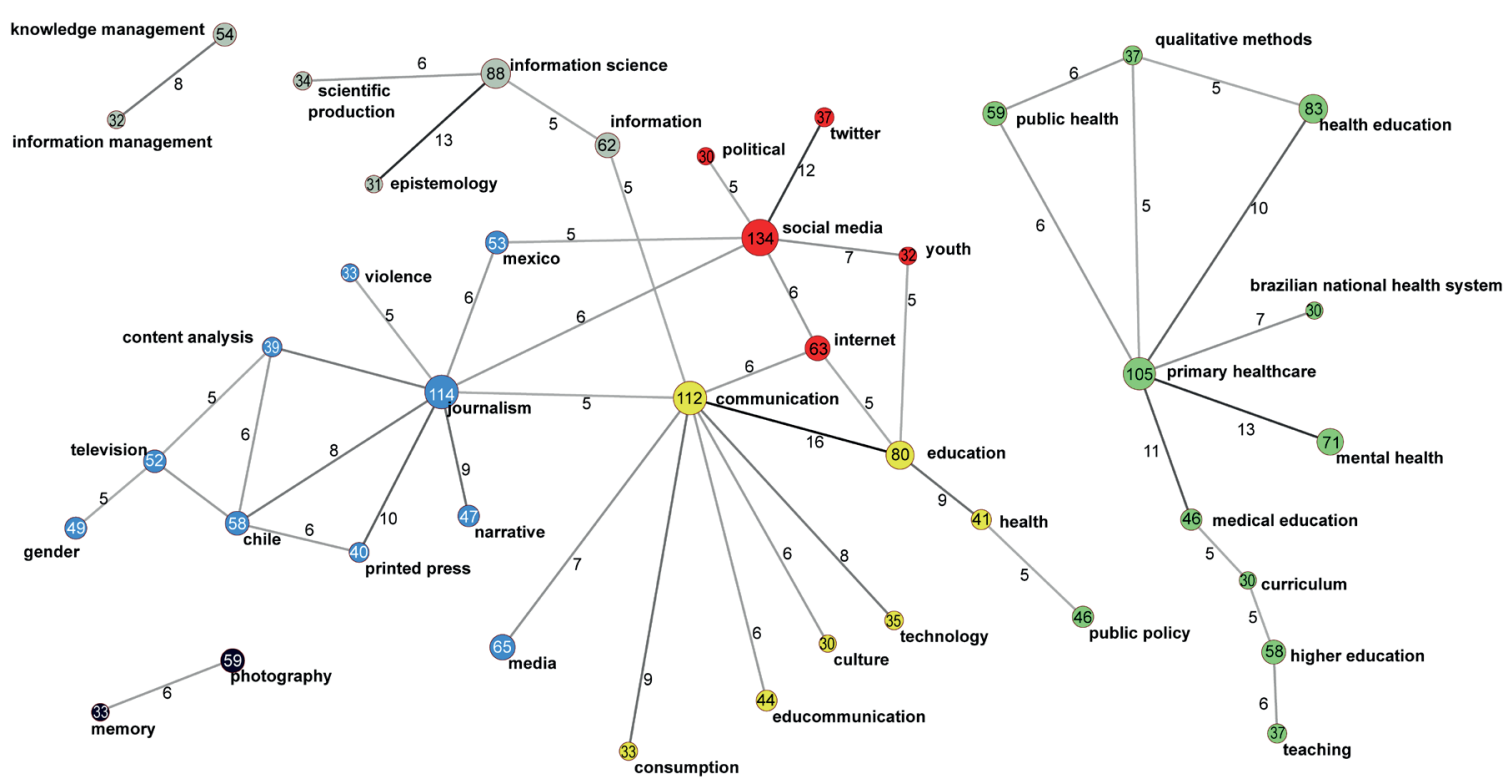

Figure 11. Network of the most frequent co-words of Latin American Communication literature in Scopus (2011-2020).

Note: Only relationships with five or more occurrences are included. 

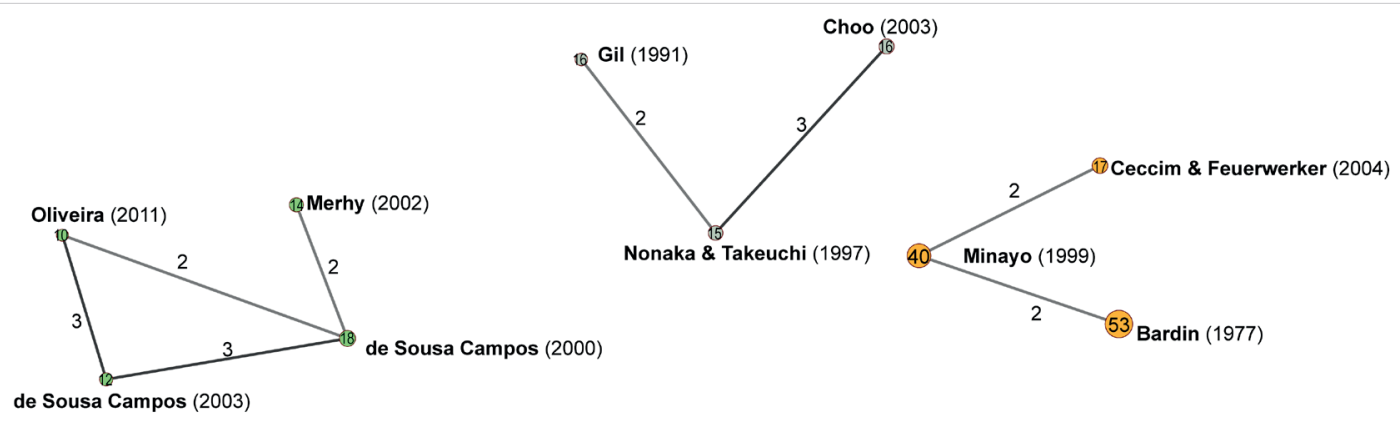

de Sousa Campos (2003)

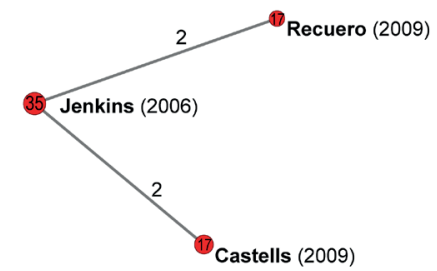

Figure 12. Cocitation network of the most cited references in Latin American Communication literature in Scopus (2011-2020). Note: Only relationships with two or more occurrences are included.

The Latin American co-word network also reveals a community structured around the concept of social networks (red) and another around journalism (blue). Unlike in the Spanish network, the repertoire of research on journalism includes attention to the narrative and violence (Fig. 11). Another community (shown in yellow) is more generic in nature, including the relationship of Communication with other areas such as culture or, especially, Education. In contrast to Europe and Spain, attention to other media such as television is not observed. Finally, two peripheral communities focused on issues of medical education (in green) and Library \& Information Sciences (in gray) are identified.

Like the Spanish and European networks, the Latin American cocitation network exhibits a community (red nodes) dedicated to the social and cultural effects of new technologies (Fig. 12). Likewise, the blue cluster can be considered analogous to the journalism community appearing in Figs. 8 and 10.

In the same way, there is a cluster on methodology (shown in orange) whose referents are different from the Spanish ones. The methodology reference common to Spain and Latin America (Bardin, 1977) appears to be linked to one of the two communities related to health (shown in green and orange), which remain in this network.

\section{Discussion and conclusions}

The grouping and transitivity coefficients of the co-word and cocitation networks indicate that the structural evolution of Spanish Communication research shows a marked trend towards conceptual and intellectual dispersion. In other words, the increase in Spanish scientific production has not occurred around a single conceptual and thematic nucleus, but has been divided between communities that are relatively disconnected from each other and with weak internal ties. In general, the low transitivity and high grouping coefficient indicate the existence of different thematic and intellectual nuclei separated from each other, around which other, more specialized communities that share more common and interchangeable conceptual interests and references are organized.

On the other hand, Spanish Communication literature exhibits greater thematic coherence (i.e., what is researched) than intellectual coherence (i.e., which perspectives or theoretical foundations are applied). Therefore, there is a greater integration between the themes and issues that Spanish researchers decide to address than the intellectual tools that they apply to interpret or make sense of those results. To paraphrase Bernard of Chartres, Spanish Communication researchers still do not agree regarding the shoulders of which giants they should stand to see further.

The division between communities is greater in the thematic than intellectual structure. It therefore exhibits greater cohesion within the different communities. Intellectually, Spanish research shows signs of greater integration than that of Latin America but clearly less than in the European context.

The composition of the networks can highlight positive maturity traits in their evolution. Thus, in the first place, the elements of other disciplines such as Library \& Information Sciences have disappeared since 2011, and both the references and topics now correspond specifically to Communication. This phenomenon is parallel to the displacement of researchers outside the discipline as indicated by co-authorship network analysis (Segado-Boj; Prieto-Gutiérrez; Díaz-Campo, 2021). In contrast, the presence of these terms and references remains common in the Latin American case in the last period, while on the European stage, their presence has been anecdotal since the end The increase in Spanish production in Scopus has resulted in a greater thematic variety and a certain dispersion of intellectual references 
In this sense, in general, the themes and references seen in Spanish Communication research remain closer to those of Europe than Latin America. In a broad sense, Spain adopts the thematic and intellectual features that defined European research in previous periods. Thus, the orientation towards the internet and new technologies experienced in Europe in the decade 2001-2010 is included and intensified in the period 2011-2020 in Spain. In this way, Spanish Communication researchers seem to be following in the footprints of their European colleagues. The lead observed for Europe in terms of the issues considered has blurred in recent years, possibly due to the intensification of relations between the Spanish and European academic networks.

The results of the work also confirm the thematic orientation of the discipline towards mass Communication (Caffarel-Serra; Ortega-Mohedano; Gaitán-Moya, 2017; Martínez-Nicolás; Saperas-Lapiedra; Carrasco-Campos, 2019). Specifically, communication research in Spain is characterized by preferential attention to digital technologies, with a clear emphasis on social networks since 2011. The emergence of the internet as an object of study is not a phenomenon exclusive to Spanish research, but rather occurs globally in this discipline (Montero-Díaz et al., 2018).

Among traditional media, the most frequently studied are the press, linked to journalism, and television. During the last decade, the latter has included investigation especially on aspects related to audiences, advertising, and information. However, its role as entertainment is absent. Likewise, Spanish Communication research exhibits a marked preference toward Journalism.

Indeed, Spanish Communication research is mainly structured around investigation in Journalism (Fig. 7). The other two classic disciplines (Audiovisual Communication, and Advertising and Public Relations) that formed the basis of early courses offered by the first Communication faculties did not develop into a coherent or relatively cohesive thematic and intellectual community in recent years. The closest conceptual connections occur between theoretical references of journalism, in addition to those referring to communication and digital culture, which constitute their own community. On the contrary, there are no connections or consolidated communities between references from other fields (Figs. 7 and 8 ).

However, this field of Journalism is not only observed in the Spanish context but is also found and with greater intensity in the European literature (Figs. 4 and 10).

This absence of consolidated intellectual communities and traditions within Advertising and Public Relations, as well as Audiovisual Communication, can be understood on the basis of the disintegration of the different traditions or fields of study addressed in these areas, or the absence of a traditional common theory that links these areas or around which they are organized.

Note also that some of the scientific literature on both Advertising and Audiovisual Communication may be published in other fields. Advertising and Public Relations jobs can be found in Business and Management magazines, and in particular, research on Audiovisual Communication can adopt a framework more oriented toward the Humanities, Arts, and the History of audiovisual media, particularly cinema. Another non-exclusive explanation is that Advertising and Audiovisual Communication have been integrated at least partially within studies on new technologies, as may be deduced from the importance reflected in the popularity of references on the transmedia phenomenon (e.g., Scolari, 2013).

Intellectually, Spanish Communication research developed from some fundamentals structured around discourse analysis toward others dedicated to message analysis, especially from the perspective of framing. The results also confirm the importance of content analysis for Spanish literature, in line with the findings of previous studies (Castillo-Esparcia; Carretón-Ballester, 2010; Gómez-Escalonilla, 2020). Indeed, this is the only tool appearing in the top 50 most used keywords. Qualitative methods, which achieve a certain presence in the first years analyzed, especially in the case of ethnography, disappear in recent years, but are found among the most frequent keywords in Europe (discourse analysis, ethnography) and Latin America (qualitative methods, discourse analysis).

Note likewise that, while the methodological studies in Spain and Latin America are directed toward general methodology manuals, in the European case, methodological work has a more specific and specialized nature. This tendency can be considered to represent another shortcoming of the discipline in Spain.

The importance of qualitative methodology in Latin American research had been indicated before (Piñeiro-Naval; Morais, 2019), but those analyses do not describe an orientation towards the cinematographic message. In fact, according to the results herein, cinema occupies a marginal position, if any. This difference may be due to the fact that our sample includes all the journals included within the Communication category of Scopus, while the cited study restricted its corpus to a selection of Spanish and Latin American journals.
Intellectually and thematically, Spanish research in Communication is closer to Europe than to Latin America 
Likewise, the cited study is restricted to Spanish literature in a specific type of medium, i.e., scientific journals. Before the "Aneca effect" (the consequence of the National Agency for Quality Assessment and Accreditation -Aneca- valuing only articles published in high-impact journals) publication was dominantly via other channels, especially books. This not only conditions the measurement of productivity but also has implications for the performance calculations, which are based on cited publications. Scientific journals prioritize a more empirical type of research, leaving less space for other types of publications such as monographs. This may explain the lack of works considered to be "fundamental" or "foundational" in Spanish Communication research. Likewise, the results for the first two decades, when Spanish production was directed towards other channels and forms of publication, may not be representative of the discipline as a whole.

\section{References}

Acosta-Cruz, María (2014). Dream nation: Puerto Rican culture and the fictions of independence. Rutgers University Press. ISBN: 9780813565477

Anderson, Benedict (1983). Imagined communities: reflections on the origin and spread of nationalism. London: Verso. ISBN: 9780860917595

Aparicio, Gloria; Iturralde, Txomin; Maseda, Amaia (2019). “Conceptual structure and perspectives on entrepreneurship education research: A bibliometric review". European research on management and business economics, v. 25, n. 3 , pp. 105-113.

https://doi.org/10.1016/j.iedeen.2019.04.003

Baladrón-Pazos, Antonio J.; Manchado-Pérez, Benjamín; Correyero-Ruiz, Beatriz (2017). “Estudio bibliométrico sobre la investigación en publicidad en España: temáticas, investigadores, redes y centros de producción (1980-2015)". Revista española de documentación científica, v. 40, n. 2, 170.

https://doi.org/10.3989/redc.2017.2.1411

Bardin, Laurence (1977). Análise de conteúdo. Lisboa: Edições Persona.

https://ia802902.us.archive.org/8/items/bardin-laurence-analise-de-conteudo/bardin-laurence-analise-de-conteudo.pdf

Batagelj, Vladimir; Mrvar, Andrej (1998). “Pajek: Program for large network analysis”. Connections, v. 21, n. 2, pp. $47-57$. http://vlado.fmf.uni-lj.si/pub/networks../doc/pajek.pdf

Billig, Michael (1995). Banal nationalism. London: Sage Publications. ISBN: 9781446221648

https://doi.org/10.4135/9781446221648

Caffarel-Serra, Carmen; Ortega-Mohedano, Félix; Gaitán-Moya, Juan-Antonio (2017). “Investigación en Comunicación en la universidad española en el período 2007-2014”. El profesional de la información, v. 26, n. 2, pp. 218-227.

https://doi.org/10.3145/epi.2017.mar.08

Campos-Domínguez, Eva (2017). "Twitter y la comunicación política". El profesional de la información, v. 26, n. 5, pp. 785-794.

https://doi.org/10.3145/epi.2017.sep.01

Castells, Manuel (2009). Communication power. Oxford: Oxford University Press. ISBN: 9780199567041

Castells, Manuel (2012). Networks of outrage and hope: social movements in the internet age. Cambridge: Polity Press. ISBN: 9780745695761

Castillo-Esparcia, Antonio; Carretón-Ballester, Carmen (2010). "Research in communication. Bibliometric study in journals of communication in Spain". Communication \& society, v. 23, n. 2, pp. 289-327.

https://revistas.unav.edu/index.php/communication-and-society/article/view/36234

Castillo-Esparcia, Antonio; Carretón-Ballester, Carmen; Pineda-Martínez, Paula (2020). "Public relations research in Spain". El profesional de la información, v. 29, n. 3.

https://doi.org/10.3145/epi.2020.may.30

Cheng, Mingming; Edwards, Deborah; Darcy, Simon; Redfern, Kylie (2018). "A tri-method approach to a review of adventure tourism literature: Bibliometric analysis, content analysis, and a quantitative systematic literature review". Journal of hospitality \& tourism research, v. 42, n. 6, pp. 997-1020.

https://doi.org/10.1177/1096348016640588

De-Filippo, Daniela (2013). "Spanish scientific output in communication sciences in WoS. The scientific journals in SSCI (2007-12). [La producción científica española en comunicación en WOS. Las revistas indexadas en SSCI (2007-12)]". Comunicar, v. 21, n. 41, pp. 25-34.

https://doi.org/10.3916/C41-2013-02

Díaz-Campo, Jesús (2016). "Análisis bibliométrico de las tesis doctorales sobre internet en las universidades españolas (1996-2011)". Transinformação, v. 28, n. 3, pp. 337-348.

https://doi.org/10.1590/2318-08892016000300008 
Díaz-Campo, Jesús; Segado-Boj, Francisco (2017). “Análisis de la investigación sobre ética de la comunicación en España (1980-2015)". Estudios sobre el mensaje periodístico, v. 23, n. 2, pp. 759-772.

https://doi.org/10.5209/ESMP.58014

Entman, Robert M. (1993). “Framing: Toward clarification of a fractured paradigm”. Journal of communication, v. 43, n. 4, pp. 51-58. https://doi.org/10.1111/j.1460-2466.1993.tb01304.x

Escribà-Sales, Eudald; Cortiñas, Sergi (2013). "Internationalization and coauthorship in major communication journals in Spain. [La internacionalización y las coautorías en las principales revistas científicas de Comunicación en España]". Comunicar, v. 21, n. 41, pp. 35-44.

https://doi.org/10.3916/C41-2013-03

Fairclough, Norman (1995). Media discourse. London: Hodder Arnold. ISBN: 9780340588895

Fatt, Choong-Kwai; Ujum, Ephrance-Abu; Ratnavelu, Kuru (2010). "The structure of collaboration in the Journal of finance". Scientometrics, n. 85, pp. 849-860.

https://doi.org/10.1007/s11192-010-0254-0

Fernández-Quijada, David; Masip, Pere (2013). “Three decades of Spanish communication research: Towards legal age. [Tres décadas de investigación española en comunicación: hacia la mayoría de edad]". Comunicar, v. 21, n. 41, pp. $15-24$. https://doi.org/10.3916/C41-2013-01

Fernández-Quijada, David; Masip, Pere; Bergillos, Ignacio (2013). “El precio de la internacionalidad: La dualidad en los patrones de publicación de los investigadores españoles en comunicación”. Revista española de documentación científica, v. 36, n. 2. https://doi.org/10.3989/redc.2013.2.936

Galtung, Johan; Ruge, Mari-Holmboe (1965). "The structure of foreign news: The presentation of the Congo, Cuba and Cyprus crises in four Norwegian newspapers". Journal of peace research, v. 2, n. 1, pp. 64-90.

https://doi.org/10.1177/002234336500200104

García-Lillo, Francisco; Claver-Cortés, Enrique; Marco-Lajara, Bartolomé; Úbeda-García, Mercedes (2017). “Mapping the intellectual structure of research on 'born global' firms and INVs: A citation/co-citation analysis". Management international review, v. 57, n. 4, pp. 631-652.

https://doi.org/10.1007/s11575-016-0308-5

Giménez-Toledo, Elea; Jiménez-Contreras, Evaristo (2013). "Black holes of communication scientific communication and meta-research. [Los agujeros negros de la comunicación: Comunicación científica y metainvestigación]”. Comunicar, v. 21, n. 41 , pp. $10-13$.

https://doi.org/10.3916/C41-2013-a2

Gómez-Calderón, Bernardo; Roses, Sergio (2015). “Autores españoles altamente productivos en comunicación (20092013): perfil, impacto e internacionalización". Opción, v. 31, n. Especial 4, pp. 499-516.

https://www.produccioncientificaluz.org/index.php/opcion/article/view/20566

Gómez-Escalonilla, Gloria (2020). "La investigación en comunicación en las universidades españolas". Comunicación y métodos, v. 2, n. 2, pp. 65-79.

https://doi.org/10.35951/v2i2.83

González-Samé, Héctor; Romero-Rodríguez, Luis-Miguel; Aguaded, Ignacio (2017). “La investigación en comunicación en Latinoamérica: Una aproximación histórica (1950-2016)". Historia y comunicación social, v. 22, n. 2, pp. $427-445$. https://doi.org/10.5209/HICS.57853

Goyanes, Manuel; Rodríguez-Gómez, Eduardo-Francisco; Rosique-Cedillo, Gloria (2018). “Investigación en comunicación en revistas científicas en España (2005-2015): de disquisiciones teóricas a investigación basada en evidencias". Profesional de la información, v. 27, n. 5, pp. 1281-1291.

https://doi.org/10.3145/epi.2018.nov.11

Giddens, Anthony (1990). The consequences of modernity. Cambridge: Polity Press. ISBN: 9780745609232

Habermas, Jürgen (1989). The structural transformation of the public sphere. An inquiry into a category of Bourgeois Society. Cambridge: MIT Press. ISBN: 9780262081801

Hallin, Daniel C.; Mancini, Paolo (2004). Comparing media systems: Three models of media and politics. Cambridge University Press. ISBN: 9780511790867

Harcup, Tony; O'Neill, Deirdre (2001). "What is news? Galtung and Ruge revisited”. Journalism studies, v. 2, n. 2, pp. $261-280$. https://doi.org/10.1080/14616700118449

Hicks, Daniel J.; Coil, David A.; Stahmer, Carl G.; Eisen, Jonathan A. (2019). "Network analysis to evaluate the impact of research funding on research community consolidation". PLoS one, v. 14, n. 6, e0218273.

https://doi.org/10.1371/journal.pone.0218273 
Jenkins, Henry (2006). Convergence culture: where old and new media collide. New York: New York University Press. ISBN: 9780814742952

Jones, Daniel E. (1998). “Investigación sobre comunicación en España: evolución y perspectivas”. Zer, v. 3, n. 5, pp. $13-51$. https://ojs.ehu.eus/index.php/Zer/article/view/17359

Lozano-Ascencio, Carlos; Gaitán-Moya, Juan-Antonio; Caffarel-Serra, Carmen; Piñuel-Raigada, José-Luis (2020). “Una década de investigación universitaria sobre Comunicación en España, 2007-2018”. Profesional de la información, v. 29 , n. 4. https://doi.org/10.3145/epi.2020.jul.12

Marcos-Recio, Juan-Carlos; Martínez-Pestaña, María-Jesús; Blasco-López, María-Francisca (2012). "Producción y dirección de tesis doctorales sobre publicidad en la universidad española (1971-2010)". Revista española de documentación científica, v. 35, n. 3, pp. 433-452.

https://doi.org/10.3989/redc.2012.3.890

Martínez-Nicolás, Manuel (2020). “La investigación sobre Comunicación en España (1985-2015). Contexto institucional, comunidad académica y producción científica". Revista latina de comunicación social, n. 75, pp. 383-414.

https://doi.org/10.4185/RLCS-2020-1432

Martínez-Nicolas, Manuel; Saperas-Lapiedra, Enric (2011). “La investigación sobre Comunicación en España (1998-2007). Análisis de los artículos publicados en revistas científicas". Revista latina de comunicación social, n. 66, pp. 101-129.

https://doi.org/10.4185/RLCS-66-2011-926-101-129

Martínez-Nicolás, Manuel; Saperas-Lapiedra, Enric; Carrasco-Campos, Ángel (2019). “La investigación sobre Comunicación en España en los últimos 25 años (1990-2014). Objetos de estudio y métodos aplicados en los trabajos publicados en revistas españolas especializadas". Empiria. Revista de metodología de ciencias sociales, n. 42, pp. 37-69.

https://doi.org/10.5944/empiria.42.2019.23250

Masip, Pere (2011). "Los efectos del efecto Aneca. Análisis de la producción española en comunicación en el Social Sciences Citation Index". En: Actas del I Congreso nacional de metodología de la investigación en comunicación. ISBN: 9788469427132

https://www.revistacomunicar.com/pdf/documentos/2011-04-Masip.pdf

McCombs, Maxwell; Shaw, Donald L. (1972). "The agenda-setting function of mass media”. Public opinion quarterly, v. 36, n. 2, pp. 176-187.

https://www.jstor.org/stable/2747787

Míguez-González, María-Isabel; Baamonde-Silva, Xosé-Manuel; Corbacho-Valencia, Juan-Manuel (2014). “A bibliographic study of public relations in Spanish media and Communication journals, 2000-2012". Public relations review, v. 40, n. 5, pp. 818-828.

https://doi.org/10.1016/j.pubrev.2014.08.002

Míguez-González, María-Isabel; Costa-Sánchez, Carmen (2019). “Tendencias de investigación sobre comunicación organizacional: la autoría española en revistas indexadas (2014-2018)”. El profesional de la información, v. 28 , n. 5. https://doi.org/10.3145/epi.2019.sep.10

Montero-Díaz, Julio; Cobo, Manuel-Jesús; Gutiérrez-Salcedo, María; Segado-Boj, Francisco; Herrera-Viedma, Enrique (2018). "A science mapping analysis of 'Communication' WoS subject category (1980-2013). [Mapeo científico de la Categoría ‘Comunicación' en WoS (1980-2013)]”. Comunicar, v. 26, n. 55, pp. 81-91.

https://doi.org/10.3916/C55-2018-08

Moreno-Delgado, Alicia; Repiso, Rafael; Montero-Díaz, Julio (2020). “Análisis de redes sociales de la producción científica sobre programación televisiva". Icono 14, v. 18, n. 1, pp. 123-154.

https://doi.org/10.7195/ri14.v18i1.1484

Olmeda-Gómez, Carlos; Perianes-Rodríguez, Antonio; Ovalle-Perandones, María-Antonia; De-Moya-Anegón, Félix (2008). "Comparative analysis of university-government-enterprise co-authorship networks in three scientific domains in the region of Madrid". Information research, v. 13, n. 3.

http://informationr.net/ir/13-3/paper352.html

Piñeiro-Naval, Valeriano; Morais, Ricardo (2019). "Study of the academic production on communication in Spain and Latin America. [Estudio de la producción académica sobre comunicación en España e Hispanoamérica]". Comunicar, n. 61, pp. 113-123.

https://doi.org/10.3916/C61-2019-10

Repiso-Caballero, Rafael; Torres-Salinas, Daniel; Delgado-López-Cózar, Emilio (2011). “Bibliometric and social network analysis applied to television dissertations presented in Spain (1976/2007). [Análisis bibliométrico y de redes sociales en tesis doctorales españolas sobre televisión (1976/2007)". Comunicar, v. 19, n. 37, pp. 151-159.

https://doi.org/10.3916/C37-2011-03-07 
Rodríguez-Gómez, Eduardo-Francisco; Goyanes, Manuel; Rosique-Cedillo, Gloria (2018). “Communication research in Spain: labor temporality, intensive production and competitiveness". Communication \& society, v. 31, n. 4, pp. $229-242$. https://revistas.unav.edu/index.php/communication-and-society/article/view/35684

Saperas-Lapiedra, Enric (2016). “Cuatro décadas de investigación comunicativa en España. Los procesos de institucionalización y de profesionalización de la investigación (1971-2015)". Disertaciones. Anuario electrónico de estudios de comunicación social, v. 9, n. 2, pp. 27-45.

https://doi.org/10.12804/disertaciones.09.02.2016.02

Schoen, Martin W.; Moreland-Russell, Sarah; Prewitt, Kim; Carothers, Bobbi J. (2014). "Social network analysis of public health programs to measure partnership". Social science and medicine, v. 123, pp. 90-95.

https://doi.org/10.1016/j.socscimed.2014.10.057

Scolari, Carlos A. (2013). Narrativas transmedia: cuando todos los medios cuentan. Barcelona: Deusto. ISBN: 97884 23413362

Segado-Boj, Francisco; Martín-Quevedo, Juan; Fernández-Gómez, Erika (2022). “Research on television series: a bibliometric analysis". Serials Librarian. First online.

https://doi.org/10.1080/0361526X.2021.2011820

Segado-Boj, Francisco; Prieto-Gutiérrez, Juan-José; Díaz-Campo, Jesús (2020). “Redes de coautorías de la investigación española y latinoamericana en Comunicación (2000-2019): cohesión interna y aislamiento transcontinental". Profesional de la información, v. 30, n. 3.

https://doi.org/10.3145/epi.2021.may.05

Small, Henry (1973). "Co-citation in the scientific literature: A new measure of the relationship between two documents". Journal of the American Society for Information Science, v. 24, n. 4, pp. 265-269.

https://doi.org/10.1002/asi.4630240406

Sosa, Manuel E.; Eppinger, Steven D.; Rowles, Craig M. (2007). "A network approach to define modularity of components in complex products". Journal of mechanical design, v. 129, n. 11, pp. 1118-1129.

https://doi.org/10.1115/1.2771182

Tang, Muh-Chyun; Teng, Weijen; Lin, Miaohua (2019). “Determining the critical thresholds for co-word network based on the theory of percolation transition: A case study in Buddhist studies". Journal of documentation, v. 76, n. 2, pp. 462483.

https://doi.org/10.1108/JD-06-2019-0117

Toury, Gideon (1995). Descriptive translation studies and beyond. Amsterdam-Philadelphia: John Benjamins Publishing. ISBN: 9789027224491

Trabadela-Robles, Javier; Nuño-Moral, María-Victoria; Guerrero-Bote, Vicente P.; De-Moya-Anegón, Félix (2020). “Análisis de dominios científicos nacionales en Comunicación (Scopus, 2003-2018)”. Profesional de la información, v. 29 , n. 4. https://doi.org/10.3145/epi.2020.jul.18

Tuchman, Gaye (1978). Making news: a study in the construction of reality. New York: Free Press.

Túñez-López, José-Miguel (2013). “The 'h-index' in Communication research in Spain, Portugal and Latin America: Web of Knowledge (WoK), Scopus and Google Scholar Metrics". Communication \& society, v. 26, n. 4, pp. 53-75. https://revistas.unav.edu/index.php/communication-and-society/article/view/36060

Van-Eck, Nees-Jan; Waltman, Ludo (2010). "Software survey: VOSviewer, a computer program for bibliometric mapping". Scientometrics, v. 84, n. 2, pp. 523-538.

https://doi.org/10.1007/s11192-009-0146-3

Vizoso, Ángel; Pérez-Seijo, Sara; López-García, Xosé (2019). “Diez años de investigación en las principales revistas científicas de comunicación. Tendencias y temáticas en las publicaciones de mayor impacto en JCR y SJR". adComunica, n. 18, pp. 245-270.

https://doi.org/10.6035/2174-0992.2019.18.12

Yan, Erjia; Ding, Ying; Zhu, Qinghua (2010). “Mapping library and information science in China: A coauthorship network analysis". Scientometrics, v. 83, n. 1, pp. 115-131.

https://doi.org/10.1007/s11192-009-0027-9

Zhu, Wenjia; Guan, Jiancheng (2013). “A bibliometric study of service innovation research: based on complex network analysis". Scientometrics, v. 94, n. 3, pp. 1195-1216.

https://doi.org/10.1007/s11192-012-0888-1 